\title{
ANALISIS BUKU AJAR BAHASA ARAB KURIKULUM 2013 MADRASAH ALIYAH KELAS X
}

\author{
Alam Budi Kusuma, Nunung Sair \\ STAI Masjid Syuhada Yogyakarta \\ alambudi.kusuma@yahoo.com
}

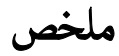

تهدف هذه الدراسة الى تحديد عرض الموار في كتاب المقرر عند منهج الدراسي

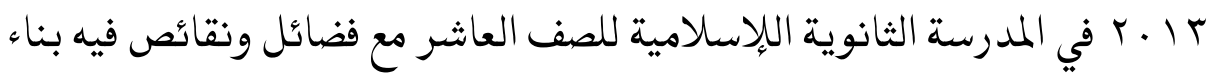

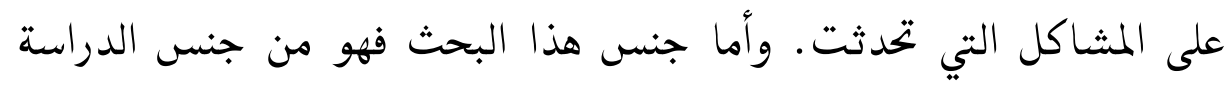

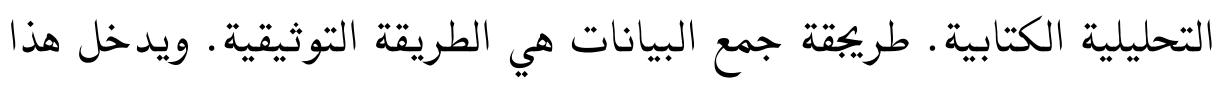

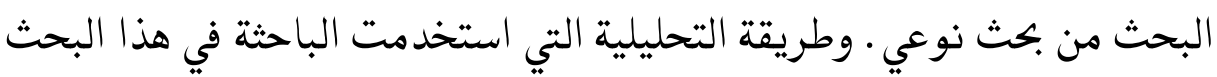

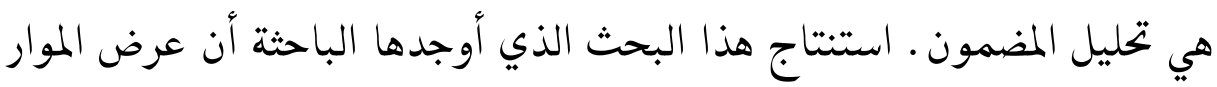

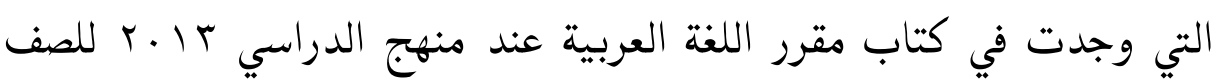

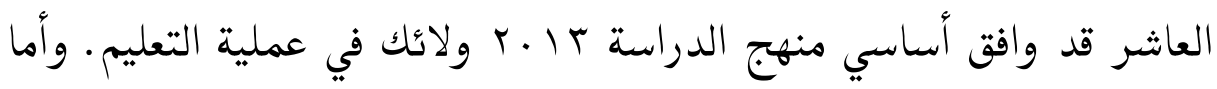

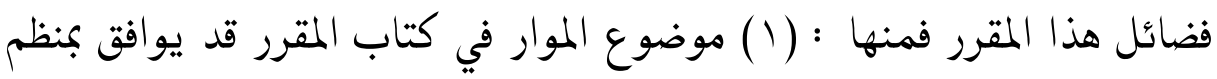

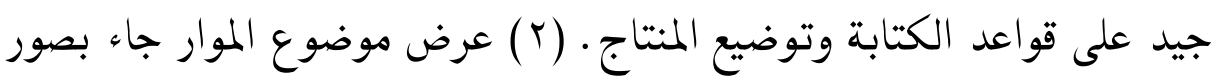

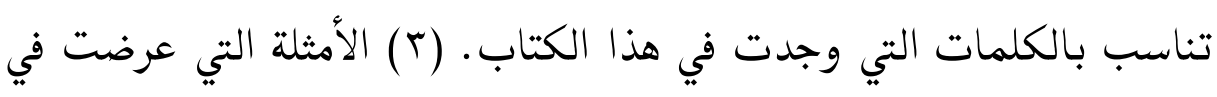

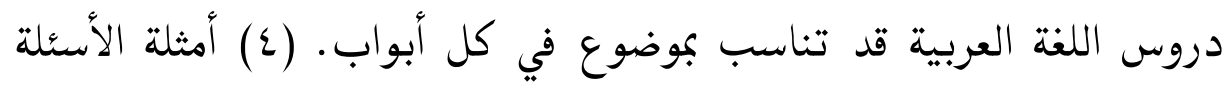

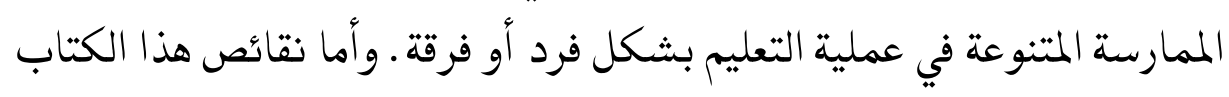

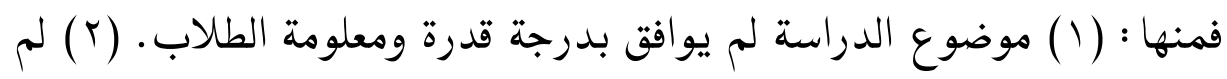

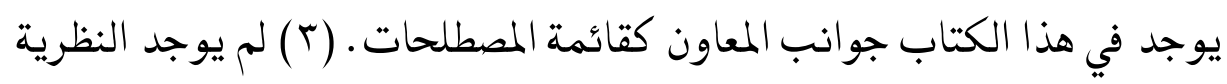
العامة أو الخلاصة التي تتعلق بموضوع هذا الكتاب. 


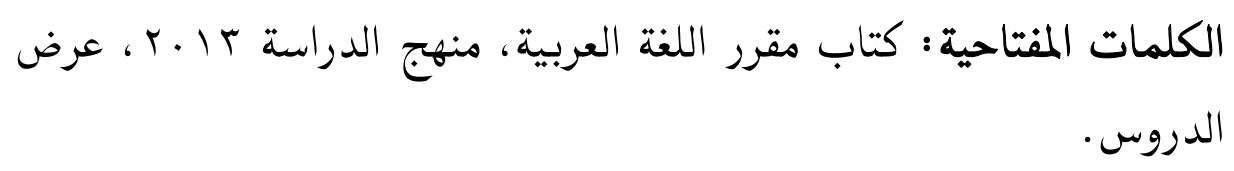

\section{Pendahuluan}

Bahasa Arab sampai saat ini masih menjadi pelajaran yang di takuti oleh banyak siswa disekolah. Sebenarnya tidak demikian, tanggapan siswa tersebut muncul akibat penyeleksian materi, urutan, dan tata cara penyajian yang masih belum sesuai dengan pelajar Indonesia. Selama ini buku-buku referensi yang menjadi bahan rujukan pembelajaran bahasa Arab berasal dari negaranegara di kawasan Jazirah Arab yang belum disesuaikan dengan pengajaran bahasa Arab siswa di Indonesia. Dengan demikian, bukan berarti materi, urutan, dan cara penyajian hanya cocok untuk pelajar asli Arab dan tidak cocok untuk pelajar Indonesia. Namun, alangkah baiknya buku ajar bahasa Arab disusun berdasarkan kemampuan dan pengetahuan siswa di masingmasing lingkungan tempat tinggalnya.

Dari fenomena tersebut tampak bahwa, pengadaan buku ajar mata pelajaran bahasa Arab dirasa sangat penting, mulai dari jenjang Ibtidaiyah, Tsanawiyah, Aliyah, sampai dengan tinggat perguruan tinggi. Begitupun dengan buku ajar untuk perguruan tinggi bagi pemula, menengah, dan ahli. Buku ajar sangat berpengaruh terhadap kepribadian siswa walaupun pengaruh tersebut berbeda-beda antara satu siswa dan siswa lainnya. Dengan adanya buku, maka siswa akan terdorong untuk berpikir dan

\section{IHTIMAM}


melakukan kegiatan posistif misalnya, memecahkan masalah, mengadakan pengamatan, dan melakukan pelatihan yang di instruksikan dalam buku ajar.

Buku ajar yang berkualitas apabila memenuhi kategori sebagai buku ajar yang menarik bagi siswa, memberikan motivasi bagi siswa, memuat ilustasi yang menarik untuk siswa, mempertimbangkan aspek-aspek linguistik sesuai kemampuan dan pengetahuan siswa, materi buku ajar berhubungan dengan pelajaran lain, merangsang aktifitas siswa, terhindar dari konsep yang membuat siswa merasa bingung, sudut pandang yang jelas, menekan pada nilai-nilai anak dan dewasa, dan menghargai perbedaan pribadi dan pengguna buku ajar. 33

Bahan ajar ditetapkan sebagai alat informasi dan disimpan dalam berbagai bentuk media yang dapat membantu siswa dalam belajar sebagai perwujudan kurikulum yang berlaku. Salah satu alat belajar mengajar yaitu buku. Bermacam-macam buku yang beredar dan bisa di baca secara mandiri oleh siswa. Misalnya, buku pelajaran, buku bacaan, kamus, dan lain-lain. ${ }^{34}$ Seiring berkembangnya zaman, banyak buku ajar yang beredar di berbagai instansi pendidikan. Dengan adanya buku tersebut dapat membantu guru dan siswa dalam proses belajar mengajar yang lebih baik dan terarah. Buku ajar yang beredar disesuaikan dengan

${ }^{33}$ Ibid, hlm 8.

${ }^{34}$ Abdul Majid, Perencanaan Pembelajaran, (Bandung: PT Remaja Rosda Karya, 2013), hlm 170-171. 
Alam Budi Kusuma, Nunung Sair : Analisis Buku Ajar Bahasa Arab Kurikulum 2013 Madrasah Aliyah Kelas X

kurikulum yang berlaku. Saat ini yang berlaku di sekolah adalah kurikulum 2013. Rancangan kurikulum tersebut dibuat agar masyarakat memiliki kualitas hidup sebagai manusia yang beriman, produktif, kreatif, inovatif dan mampu berkontribusi pada kehidupan bermasyarakat, berbangsa, dan bernegara serta peradaban dunia. ${ }^{35}$ Perubahan rancangan kurikulum tentunya mempunyai dampak tersendiri, salah satu dampaknya yaitu, perubahan pada buku ajar yang digunakan dalam proses belajar mengajar.

Dengan di berlakukannya kurikulum 2013 pada mata pelajaran bahasa Arab, berdasarkan keputusan Menteri Agama Republik Indonesia Nomor 207 Tahun 2014 tentang kurikulum madrasah, menjelaskan bahwa penetapan kurikulum dalam tingkat satuan pendidikan 2006 meliputi mata pelajaran umum, sedangkan penetapan dalam kurikulum 2013 meliputi mata pelajaran Agama Islam maupun Bahasa Arab. ${ }^{36}$

Berdasarkan hasil pengamatan penulis menemukan bahwa buku Ajar bahasa Arab Kelas X Terbitan Kemenag tahun 2014, terdapat beberapa kejanggalan dalam buku ajar tersebut, yaitu adanya intruksi yang menggunakan kata-kata yang sulit dipahami siswa. Karena buku ajar seharusnya memuat pesan yang bersifat komunikatif, yakni menggunakan bahasa yang mudah dan sesuai

35 Syamsuddin Asyrofi Dan Toni Pransiska, op cit, hlm 94.

${ }^{36}$ Keputusan Menteri Agama Republik Indonesia, Nomor 207 Tahun 2014, tentang Kurikulum Madrasah, (Jakarta: Kemenag, 2014).

\section{IHTIMAM}


dengan kadar kemampuan siswa sehingga tidak menimbulkan makna atau pemahaman yang sulit. Masalah lainnya, yaitu banyak siswa yang belum pernah mempelajari bahasa Arab, karena siswa tersebut berasal dari lulusan Sekolah Menengah Pertama (SMP) yang notabene tidak mempelajari bahasa Arab. ${ }^{37}$

Selain itu, terdapat beberapa kekeliruan dalam penulisan harakat akhir dalam suatu kalimat. Karena, jika dilihat dari kondisi siswa yang berasal dari lulusan Sekolah Menengah Pertama (SMP) mayoritas siswa belum mengenal bahasa Arab. Hal ini menjadi masalah tersendiri bagi guru dalam mengajarkan bahasa Arab di jenjang Madrasah Aliyah. Berangkat dari latar belakang permasalahan diatas, penulis tertarik untuk melakukan penelitian terhadap Buku Ajar Bahasa Arab Kurikulum 2013 Madrasah Aliyah Kelas $X$, untuk mengetahui penyajian materi dalam buku ajar bahasa Arab tersebut.

\section{Pemahaman Buku Ajar (Buku Teks)}

Buku ajar atau buku teks berasal dari kata bahasa Inggris yaitu textbook atau dalam bahasa Arab yaitu al-kitabu al-madarisy. Buku merupakan materi pelajaran yang disusun sedemikian rupa untuk memudahkan siswa dalam memahami materi dalam proses pembelajaran dengan bimbingan seorang guru. Buku ajar merupakan komponen yang berperan penting dalam proses belajar

37 Hasil Pengamatan Dari Buku Ajar Bahasa Arab Kurikulum 2013 Madrasah Aliyah Kelas X 
Alam Budi Kusuma, Nunung Sair : Analisis Buku Ajar Bahasa Arab Kurikulum 2013 Madrasah Aliyah Kelas X

mengajar disuatu lembaga pendidikan. Sebab tanpa buku ajar proses belajar menajar tidak optimal dan terarah, karena buku ajar merupakan bahan ajar dan sumber informasi yang menunjang proses tercapainya tujuan pembelajaran. ${ }^{38}$

Chambliss dan Calfe dalam buku Masnur Muslich, menjelaskan bahwa buku adalah suatu sarana yang digunakan unutk membantu siswa dalam memahami hal-hal diluar dari diri mereka. Buku juga mempunyai kekuatan yang luar biasa dalam mempengaruhi perubahan otak siswa terhadap suatu nilai-nilai tertentu. Oleh karena itu, buku ajar atau buku teks di gunakan sebagai pengangan yang wajib bagi siswa dan guru untuk kelancaran proses pembelajaran di dalam kelas. ${ }^{39}$

Selain itu, dalam Peraturan Menteri Pendidikan Dan Kebudayaan (Kemendikbud) Nomor 8 Tahun 2016 dijelaskan bahwa buku ajar atau buku teks merupakan pelengkap operasional utama dalam penerapan kurikulum dan buku non-teks merupakan perangkat pendukung untuk menfasilitasi pelaksanaan, penilaian serta untuk mengembangkan pelajaran bagi guru dan siswa, sehingga memenuhi kriteria standar kelayakan buku yang dapat digunakan dalam instansi pendidikan. Dari buku ajar tersebut

38 Khairy Abusyairi, Dinamika Ilmu : "Pengembangan Bahan Ajar Bahasa Arab", (STAIN Samarinda, 2013, Volume 13, Nomor 2), hlm 51-66.

39 Masnur Muslich, Text Book Writing: Dasar-Dasar Pemahaman, Penulisan, Dan Pemakaian Buku Teks, (Yogyakarta: Ar-Ruzz Media, 2010), hlm 47-52. 
siswa dihadapkan dengan bahan ajar yang telah didokumentasikan dan memuat informasi pelajaran. ${ }^{40}$

Dalam dunia pendidikan, buku ajar selalu memegang peran penting karena buku merupakan salah satu rujukan wajib bagi instansi atau sekolah, sehingga wajar jika buku selalu mengalami perubahan dengan menyesuaikan kurikulum yang berlaku saat itu. ${ }^{41}$ buku ajar mempunyai ciri-ciri sebagai berikut :

1. Buku sekolah yang digunakan oleh siswa.

2. memuat materi yang sudah diseleksi.

3. Berkaitan dengan mata pelajaran tertentu.

4. Disusun oleh tim yang berpengalaman dibidangnya.

5. Disusun untuk tujuan intruksional tertentu.

6. Dilengkapi sarana pembelajaran.

7. Diasimilasikan dalam proses pembelajaran.

8. Buku disusun sebagai sarana punjang program dalam proses pembelajaran. ${ }^{42}$

Adapun bagian-bagian yang terdapat dalam buku ajar secara umum sebagai berikut :

1. Bagian awal, meliputi :

a. Cover dan halaman judul memuat judul, nama pengarang, gambar sampul, nama departemen, tahun terbit, dan sasaran

40 Peraturan Menteri Pendidikan Dan Kebudayaan Nomor 8 Tahun 2016 Tentang Buku Yang Digunakan Oleh Satuan Pendidikan.

${ }^{41}$ R. Ibrahim dan Nana Syaodih, Perencanaan Pembelajaran, (Jakarta: Rineka Cipta, 2010), hlm 115.

42 Masnur Muslich, op cit, hlm 51. 
Alam Budi Kusuma, Nunung Sair : Analisis Buku Ajar Bahasa Arab Kurikulum 2013 Madrasah Aliyah Kelas X

buku.

b. Lembaran hak cipta berisi tentang identitas penulis.

c. Lembaran kata pengantar yang berisi kumpulan pernyataan atau kata pengantar dari pengarang dan penerbit.

d. Lembaran daftar isi mencakup halaman judul bab, subbab, dan bagian-bagian dari buku ajar.

2. Bagian isi

Pada bagian isi berisi bab-bab, yang mana setiap bab terdiri dari subbab-subbab yang menjelaskan atau menjabarkan tentang materi buku dan soal-soal latihan di lembar kerja siswa.

3. Bagian akhir, meliputi :

a. Indeks yaitu daftar kata atau istilah-istilah dalam materi buku ajar, disusun berdasarkan abjad untuk memudahkan siswa dalam mencari halaman kata atau istilah yang tertulis dalam buku teks.

b. Glosarium yaitu penjelasan singkat mengenai istilah-istilah atau kata yang berhubungan dengan materi dalam buku ajar.

c. Daftar pustaka memuat daftar referensi yang relevan dalam penyusunan sebuah buku ajar.

d. Ikhtisar yaitu sebuah ringkasan atau penjelasan singkat tentang isi buku tersebut.

Dalam peraturan Menteri Pendidikan Naisonal Nomor 11 tahun 2005 dijelaskan bahwa buku ajar adalah buku pelajaran yang merupakan acuan wajib yang digunakan sekolah dalam proses pembelajaran dalam rangka meningkatkan keimanan dan 
ketakwaan, budi pekerti dan kepribadian, kemampuan menguasai ilmu pengetahuan dan teknologi, kepekaan dan kemampuan estetis, serta potensi fisik dan kesehatan yang disusun berdasarkan standar nasional pendidikan. ${ }^{43}$

1. Macam-macam buku ajar

Menurut H.G Taringan ada 4 dasar yang digunakan dalam mengklasifikasi buku ajar sebagai berikut :

a. Berdasarkan mata pelajaran atau bidang studi tertentu.

b. Berdasarkan mata kuliah bidang studi yang bersangkutan.

c. Berdasarkan penulisan buku ajar.

d. Berdasarkan jumlah penulisan buku ajar.

Dilihat dari cara penulisan buku ajar dikenal tiga jenis buku yang umumnya digunakan, yaitu :

a. Buku teks tunggal, yaitu hanya terdiri dari satu buku teks.

b. Buku teks berjilid, yaitu buku ajar yang digunakan hanya untuk satu kelas tertentu atau untuk jenjang sekolah tertentu.

c. Buku teks berseri, yaitu buku yang meliputi beberapa jenjang sekolah seperti SD, SMP, dan SMA sederajat.

Secara umum buku dibedakan menjadi empat jenis, yaitu sebagai berikut :

a. Buku sumber adalah buku ajar yang dijadikan rujukan, referensi dan sumber kajian ilmu yang disajikan secara rinci.

${ }^{43} \mathrm{Ibid}, \mathrm{hlm} 50$. 
Alam Budi Kusuma, Nunung Sair : Analisis Buku Ajar Bahasa Arab Kurikulum 2013 Madrasah Aliyah Kelas X

b. Buku bacaan adalah buku yang berfungsi sebagai bahasan bacaan saja misalnya cerita, legenda, novel, dan lain sebagainya.

c. Buku pegangan adalah buku yang bisa dijadikan pegangan bagi guru atau pengajar dalam proses pembelajaran.

d. Buku bahan ajar adalah buku yang disusun sedemikian rupa sehingga bisa digunakan dalam proses pembelajaran dan berisi bahan-bahan atau materi pelajaran yang akan disampaikan kepada siswa. ${ }^{44}$

Syamsuddin Asyrofi dalam bukunya yang mengutip pernyataan dari Robert F. Morger menyatakan bahwa penyusunan buku ajar bahasa Arab harus merumuskan tujuan yang ingin dicapai secara jelas sehingga mudah difahami oleh sasaran pengguna buku tersebut. Dan akan berhasil usahanya jika guru menggunakan buku ajar tersebut baik dari metode, pendekatan, teknik penyampaian sesuai dengan yang tujuan yang dimaksudkan oleh penulis buku. 45

2. Karakteristik buku ajar

Buku ajar secara umum di kategorikan dalam karya tulis ilmiah. Karena buku tersebut memiliki bentuk seperti bentuk

44 Andi Prastowo, Panduan Kreatif Membuat Bahan Ajar Inovatif Menciptakan Metode Pembelajaran Yang Menarik Dan Menyenangkan, (Yogyakarta: Diva Press, 2012), hlm 167-168.

45 Syamsuddin Asyrofi, Metodologi Pengajaran Bahasa Arab : Analisa Text Book Bahasa Arab, (Yogyakarta: Sumbangsih, 1998), hlm 9.

\section{IHTIMAM}


karya tulis ilmiah pada umumnya. Persamaannya dilihat pada hal-hal berikut :

a. Segi isi, yaitu buku ajar memuat serangkaian pengetahuan yang bisa dipertanggungjawabkan secara ilmiah.

b. Segi penyajian, yaitu materi yang diuraikan mengikuti pola penalaran tertentu, yaitu penalaran induktif, deduktif, atau campuran (kombinasi antara induktif -deduktif).

c. Segi format, buku ajar harus mengikuti aturan penulisan ilmiah, baik pola penulisan, pengutipan, pembagian, maupun pembahasannya. ${ }^{46}$

3. Komponen buku ajar

Bahan ajar yang dirancang harus memuat komponenkomponen yang dapat menunjang proses belajar mengajar disekolah. Adapun komponen-komponen buku ajar adalah sebagai berikut :

a. Buku ajar harus mampu menyajikan langkah-langkah yang mudah untuk memahami materi selama proses belajar mengajar.

b. Sebelum menyampaikan materi, perlu dijelaskan terlebih dahulu mengenai tujuan pembelajaran yang ingin dicapai. Agar bisa mengetahui tingkat pencapaian siswa terhadap materi yang disajikan,

\footnotetext{
46 Ibid, hlm 8.
} 
Alam Budi Kusuma, Nunung Sair : Analisis Buku Ajar Bahasa Arab Kurikulum 2013 Madrasah Aliyah Kelas X

c. Untuk menunjang pencapaian materi perlu disajikan kerangka isi dalam bentuk diagram agar siswa dapat mengetahui bagian-bagian yang mencakup pokok bahasan.

d. Penyajian materi pokok sampai sub pokok bahasan diuraikan secara jelas dibantu dengan gambar (ilustrasi), tabel, dan diagram.

e. Pemberian gambar dan contoh-contoh gambar digunakan untuk mendukung materi pada setiap pokok bahasan.

f. Pemberian rangkuman dibutuhkan untuk membantu siswa dalam mengingat dan menetapkan konsep materi yang disajikan pada setiap pokok bahasan.

g. Memuat soal latihan, kunci jawaban, dan tingkat penguasaan siswa merupakan suatu bentuk evaluasi yang bertujuan untuk mengetahui tingkat pencapaian tujuan dalam pembelajaran.

h. Model tugas-tugas yang disajikan dalam setiap akhir materi pembelajaran bertujuan untuk melatih tingkat berpikir dan keterampilan siswa setelah mempelajari dan memahami materi yang disajikan. ${ }^{47}$

4. Manfaat buku ajar

Buku ajar memiliki beberapa manfaat sebagai berikut :

a. Memudahkan guru dalam melaksanakan kurikulum yang sedang berlaku.

47 Abdul Hamid dkk, Pembelajaran Bahasa Arab Pendekatan, Metode, Strategi, materi, dan Media, (Malang: UIN Malang Press, 2008), hlm 80-81. 
b. Menjadi pegangan dalam menentukan metode pengajaran.

c. Memberi kesempatan bagi siswa untuk mengulang pelajaran yang telah disampaikan guru dan mempelaji materi yang baru.

d. Menentukan keururutan materi pelajaran di kelas walaupun guru yang mengajar mengalami pergantian.

e. Bisa digunakan di masa yang akan datang. Apabila mengalami revisi, dapat bertahan dalam waktu yang lama dan dapat menyesuaikan dengan kurikulum yang berlaku.

f. Memberi pengetahuan dan metode dalam pembelajaran.

g. Mampu mendorong aspirasi siswa. ${ }^{48}$

\section{Penyajian Materi Dalam Buku Ajar Bahasa Arab}

Ada beberapa hal yang perlu diperhatikan dalam menyusun dan mengembangkan buku ajar bahasa Arab menurut Abdul Hamid, yaitu sebagai berikut :

1. Isi buku ajar

Isi buku ajar bahasa Arab harus berkaitan dengan kebenaran isi secara keilmuan dengan keselarasan isi berdasarkan sistem yang dianut oleh masyarakat. Adapun kebenaran buku ajar bahasa Arab disusun berdasarkan konsep dan teori pembelajaran bahasa Arab yang didapatkan dari bukubuku yang berhubungan erat dengan bahasa Arab sedangkan

48 S. Nasirudin, Teknologi Pendidikan, (Jakarta: PT Bumi Aksara, 2011), hlm 102-103. 
Alam Budi Kusuma, Nunung Sair : Analisis Buku Ajar Bahasa Arab Kurikulum 2013 Madrasah Aliyah Kelas X

hasil penelitian empirik dan perkembangan mutakhir diperoleh dari jurnal-jurnal penelitian baik cetak maupun elektronik.

Keselarasan isi buku ajar bahasa arab disesuaikan dengan nilai falsafah hidup yang berlaku dalam suatu negara dan masyarakat di lingkungan tempat sekolah atau lembaga pendidikan tersebut didirikan.

2. Ketepatan cakupan

Ketepatan cakupan berhubungan dengan materi yang dipaparkan dalam buku ajar bahasa Arab. Hal ini dapat dilihat dari sisi keluasan dan kedalaman materi serta keutuhan konsep berdasarkan bidang keilmuan dalam pembelajaran bahasa Arab. Kedalaman dan keluasan materi sangat penting untuk menentukan tolak ukur buku ajar yang akan dikembangkan sesuai dengan kemampuan dan tingkat pendidikan yang sedang ditempuh oleh siswa.

3. Ketercenaan materi

Ada enam hal yang dapat mendorong ketercenaan materi dalam buku ajar tersebut sebagai berikut :

a. Pemaparan yang logis. Materi yang dipaparkan secara logis dapat memudahkan siswa untuk memahami materi dalam buku ajar dan bisa mengaitkan dengan informasi yang telah dipelajari sebelumnya, serta melatih siswa berpikir secara sistematis.

b. Penyajian materi yang berurutan. Hal ini dilakukan agar materi yang disajikan tidak loncat-loncat, sehingga

\section{IHTIMAM}


memudahkan siswa dalam belajar secara mandiri serta membiasakan siswa untuk berpikir secara sistematis.

c. Terdapat contoh. Tujuan utama disajikannya contoh adalah untuk memperjelas teori yang disajikan dalam buku ajar serta menarik bagi siswa dalam mempelajari materi dalam buku ajar bahasa Arab tersebut.

d. Alat bantu. Adanya alat bantu tersebut bertujuan untuk membantu siswa dalam mempelajari dan memahami materi yang disajikan dalam setiap proses pembelajaran.

e. Format yang tertib dan konsisten. Hal tersebut dapat membantu dan mempermudah siswa dalam mengenali, mengingat, dan mempelajari buku ajar bahasa Arab secara mandiri.

f. Memuat penjelasan tentang relevansi dan manfaat buku ajar. Setiap buku ajar, terutama buku ajar pelajaran bahasa Arab perlu menyajikan penjelasan tentang manfaat dan kegunaan bahan ajar dalam pembelajaran. Sebab buku ajar bahasa Arab juga mempunyai peran penting sebagai sarana utama dalam proses belajar mengajar di kelas. Buku ajar juga berfungsi sebagai alat bantu untuk memudahkan siswa belajar secara individu, berpasangan, maupun berkelompok.

4. Aspek bahasa

Penulisan buku ajar bahasa Arab perlu memperhatikan aspek yang mencakup dengan pengetahuan dasar linguistik bahasa yang meliputi suara, kosa kata, dan struktur bahasa yang 
Alam Budi Kusuma, Nunung Sair : Analisis Buku Ajar Bahasa Arab Kurikulum 2013 Madrasah Aliyah Kelas X

disesuaikan dengan kemampuan dan ketercapaian mental siswa dan linguistik siswa di masing-masing daerah.

5. Pengemasan atau perwajahan

Pengemasan atau perwajahan dalam buku ajar berhubungan dengan tata letak informasi dalam suatu media cetak dan pengemasan dalam paket buku ajar multimedia.

6. Ilustrasi

Penyajian ilustrasi dalam buku ajar bahasa Arab dengan tujuan untuk membuat buku ajar tersebut menjadi lebih menarik, mampu memberikan dorongan motivasi, bersifat komunikatif, dan dapat membantu siswa dalam memahami materi serta pesan yang disajikan dalam buku ajar. Dalam hal ini, ilustrasi meliputi: tabel, diagram, simbol, grafik, kartun, sketsa, foto, gambar, maupun skema.

7. Kelengkapan komponen

Kelengkapan komponen ini berkaitan dengan buku ajar yang berfungsi sebagai komponen utama, komponen pelengkap, dan komponen evaluasi hasil belajar. Komponen utama berisi informasi atau topik utama yang akan disampaikan kepada siswa dan harus dikuasai oleh siswa. Komponen pelengkap berupa informasi tambahan, yang terdiri dari bahan pendukung media cetak seperti, kaset, CD, dan VCD. Sedangkan komponen evaluasi terdiri atas perangkat soal-soal atau butir tes yang 
Alam Budi Kusuma, Nunung Sair : Analisis Buku Ajar Bahasa Arab Kurikulum 2013 Madrasah Aliyah Kelas X

digunakan sebagai format tes bagi siswa selama proses belajar mengajar bahasa Arab di kelas. ${ }^{49}$

\section{Gambaran Umum Buku Ajar Bahasa Arab Madrasah Aliyah Kelas X}

1. Identitas buku

Objek dalam penelitian ini adalah buku siswa mata pelajaran bahasa Arab kurikulum 2013 Madrasah Aliyah Kelas X yang diterbitkan oleh Kemenag RI tahun 2014, cetakan pertama dengan menggunakan pendekatan ilmiah (scientific approach).

Buku ajar ini dikutip dari beberapa naskah yang ditelaah oleh H.D. Hidayat dan Fuad Thahari, sedangkan kontributor naskah adalah Masrukin dan Devi Apriyanto. Penyelia penerbitan adalah Direktorat Pendidikan Madrasah, Direktorat Jendral Pendidikan Islam, dan Kementerian Agama Republik Indonesia. ${ }^{50}$

2. Deskripsi umum buku ajar bahasa Arab Kurikulum 2013 Madrasah Aliyah Kelas X

Buku ajar bahasa Arab ini terdiri dari beberapa bagian sebagai berikut :

a. Bagian pertama memuat cover, identitas buku, kata pengantar, dan daftar isi halaman i-viii.

${ }^{49}$ Abdul Hamid dkk, op cit, hlm 102-109.

${ }^{50}$ Hasil Dokumentasi Buku Ajar Bahasa Arab Kurikulum 2013 Madrasah Aliyah Kelas X, (Kemenag, 2014), hlm ii. 
Alam Budi Kusuma, Nunung Sair : Analisis Buku Ajar Bahasa Arab Kurikulum 2013 Madrasah Aliyah Kelas X

b. Bagian kedua memuat isi buku ajar halaman 1-107 terdiri atas enam bab. Pada masing-masing memuat lima subbab, yaitu mufradat, istima', hiwar, tarkib, qira'ah, dan kitabah. Pada awal bab dilengkapai dengan Kompetensi Inti (KI), Kompetensi Dasar (KD), indikator, dan tujuan pembelajaran.

c. Bagian ketiga. Berisi tentang pendekatan saintifik, terdapat lembar mengamati untuk merangsang siswa dalam berfikir mengenai materi yang disampaikan berdasarkan ilustrasi di halaman 3-4. Siswa belajar mengamati dan menirukan pelafalan kata dengan baik dan benar. Seperti contoh pada gambar di bawah ini.

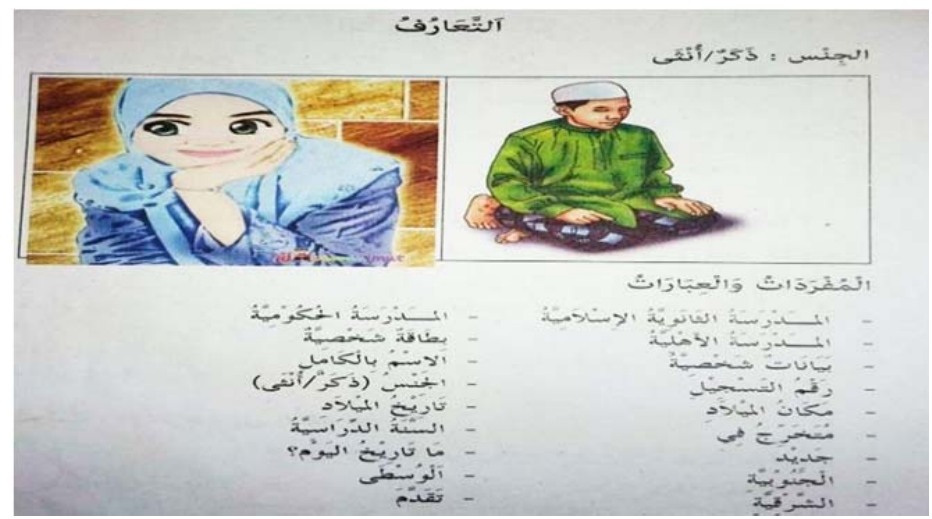

Gambar 1: Contoh Lembar Mengamati

Setelah mengamati, menyimak, dan membaca materi yang disajikan, kemudian siwa diberikan kesempatan untuk bertanya mengenai apa yang belum diketahui terkait tema yang akan dibahas. 
Alam Budi Kusuma, Nunung Sair : Analisis Buku Ajar Bahasa Arab Kurikulum 2013 Madrasah Aliyah Kelas X

d. Bagian kelima memuat lembar eksplorasi yang berkaitan dengan kompetensi inti dan kompetensi dasar serta materi pendukung lainnya. Seperti mengamati 2 perbandingan (salah dan benar) pada halaman 39.

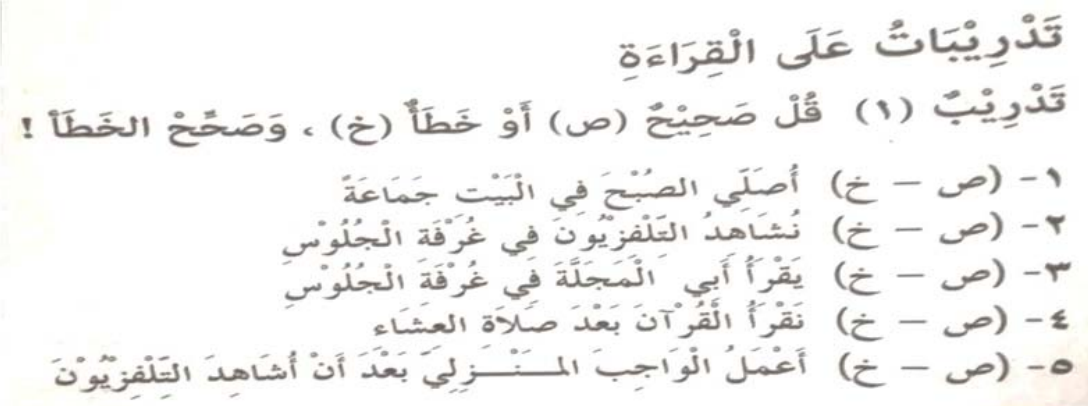

Gambar 2 : Contoh Lembar Eksplorasi

e. Bagian keenam memuat lembar evaluasi yang terdiri dari latihan-latihan siswa terkait dengan tema yang dibahas (halaman 44-49). Dengan adanya latihan siswa diharapkan dapat mengingat kembali materi-materi yang telah dipelajari. ${ }^{51}$

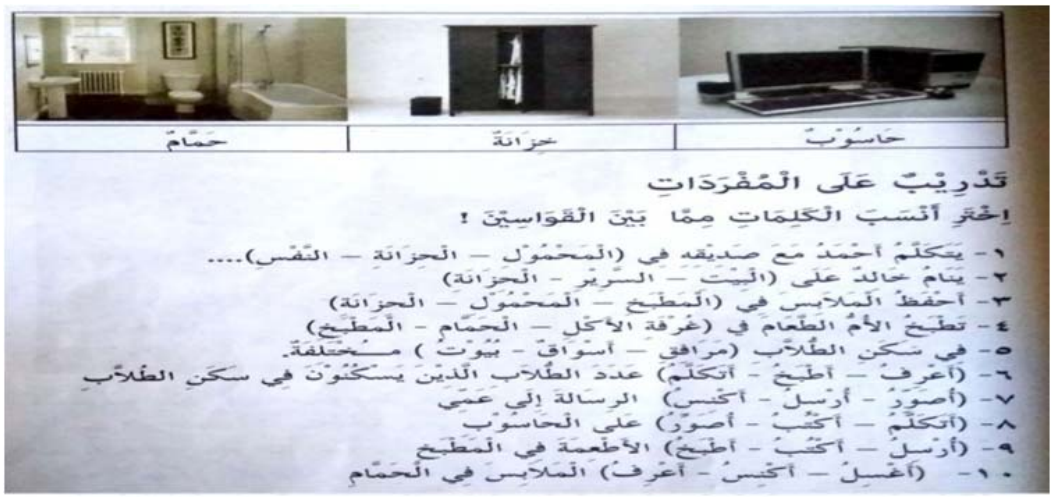

Gambar 3 : Contoh Lembar Evaluasi

${ }^{51}$ Hasil Dokumentasi Buku Ajar ...., hlm 3-109. 
Alam Budi Kusuma, Nunung Sair : Analisis Buku Ajar Bahasa Arab Kurikulum 2013 Madrasah Aliyah Kelas X

3. Hasil analisis buku ajar bahasa Arab Kurikulum 2013 Madrasah Aliyah Kelas X

Tabel 3 : Penyajian Analisis Materi Buku Ajar

\begin{tabular}{|c|c|c|}
\hline $\mathrm{Bab}$ & Isi & Jumlah Halaman \\
\hline \multirow{5}{*}{$\begin{array}{c}\text { البيانات : } 1 \text { الشخصية } 1 \text { البة } \\
\text { Bab }\end{array}$} & الأستماع & 4 (halaman 4-7) \\
\hline & الحوار & 2 (halaman 7-8) \\
\hline & التكيب & 3 (halaman 9-11) \\
\hline & القراءة & 2 (halaman 12-13) \\
\hline & الكتابة & 2 (halaman 14-15) \\
\hline \multirow{5}{*}{$\begin{array}{c}\text { Bab } 2 \text { : المرافق العامة في } \\
\text { المدرسة }\end{array}$} & الأستماع & 3 (halaman 19-21) \\
\hline & الحوار & 4 (halaman 21-24) \\
\hline & التكيب & 2 (halaman 24-25) \\
\hline & القراءة & 4 (halaman 25-28) \\
\hline & الكتابة & 2 (halaman 28-29) \\
\hline \multirow{5}{*}{$\begin{array}{c}\text { الحياة في الأسرة وفي : Bab 3 } \\
\text { السكن الطلاب }\end{array}$} & الأستماع & 1 (halaman 34) \\
\hline & الحوار & 2 (halaman 35-36) \\
\hline & التكيب & 3 (halaman 36-38) \\
\hline & القراءة & 2 (halaman 38-39) \\
\hline & الكتابة & 3 (halaman 39-41) \\
\hline \multirow{2}{*}{ 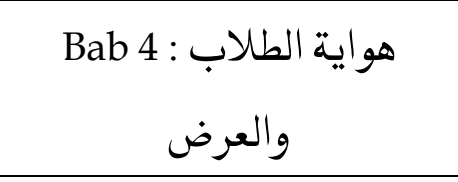 } & الأستماع & 5 (halaman 53-57) \\
\hline & الحوار & 2 (halaman 57-58) \\
\hline
\end{tabular}




\begin{tabular}{|c|c|c|}
\hline & التكيب & 9 (halaman 59-66) \\
\hline & القراءة & 4 (halaman 67-71) \\
\hline & الكتابة & 2 (halaman 72-73) \\
\hline \multirow{5}{*}{ Bab 5 : المهنة و الحياة } & الأستماع & 3 (halaman 77-79) \\
\hline & الحوار & 6 (halaman 79-84) \\
\hline & التكيب & 4 (halaman 85-88) \\
\hline & القراءة & 5 (halaman 88-92) \\
\hline & الكتابة & 2 (halaman 93-94) \\
\hline \multirow{4}{*}{ Bab 6 : المهنة والنظام } & الأستماع & 1 (halaman 98) \\
\hline & التركيب & 2 (halaman 98-99) \\
\hline & القراءة & 2 (halaman 99-101) \\
\hline & الكتابة & 8 (halaman 102-109) \\
\hline
\end{tabular}

a. Kompetensi Inti (KI)

1) Menghayati dan mengamalkan ajaran agama islam.

2) Menghayati dan mengamalkan perilaku jujur disiplin, tanggungjawab, peduli (gotong royong, kerjasama, toleran, damai), santun, responsif dan pro-aktif serta menunjukkan sikap sebagai bagian dari dari solusi atas berbagai permasalahan dalam berinteraksi secara efektif dengan lingkungan sosial dan alam serta menempatkan diri sebagai cerminan bangsa dalam pergaulan. 
Alam Budi Kusuma, Nunung Sair : Analisis Buku Ajar Bahasa Arab Kurikulum 2013 Madrasah Aliyah Kelas X

3) Memahami, menerapkan, menganalisis pengetahuan faktual, konseptual, prosedural berdasarkan rasa ingintahunya tentang ilmu pengetahuan, teknologi, seni, budaya, dengan humaniora dengan wawasan kemanusiaan, kebangsaan, kenegaraan, dan peradaban terkait penyebab fenomena dan kejadian, serta menerapkan pengetahuan prosedural pada bidang kajian yang spesifik sesuai dengan bakat dan minatnya untuk memecahkan masalah.

4) Mengolah, menalar, dan menyaji dalam ranah kongkret dan ranah abstrak terkait dengan pengembangan dari yang dipelajari disekolah secara mandiri, dan mampu menggunakan metode sesuai kaidah keilmuan.

Bab pertama yang bertema tentang "identitas pribadi" menjelaskan mengenai perkenalan manusia, terutama sebagai seorang muslim. Didilihat dari perspektif kurikulum 2013 yang terdiri dari empat kompetensi, setidaknya ada beberapa yang perlu digaris bawahi, yaitu pertama, aspek KI-1(sikap spiritual) terdapat dalam bacaan qira'ah halaman 12 yang menceritakan tentang ta'aruf yang dianjurkan bagi setiap muslim untuk saling mengenal dalam ajaran islam. Kedua, aspek KI-2 (sikap sosial) karena didalam juga menjelaskan tentang bagaimana interaksi antara sesama muslim sebagai umat manusia. 
Pada subbab tarkib dilihat lebih mendalam, menyentuh ranah pengetahuan (KI-3) berisi tentang kaidah-kaidah yang digunakan dalam bahasa Arab. Dan pada subbab kitabah yang disajikan dalam setiap tema, menyangkut aspek keterampilan (KI-4) menyajikan latihan-latihan yang dilakukan siswa secara mandiri dengan menggunakan kaidah-kaidah keilmuan yang telah dipelajari dari tema-tema pada setiap bab.

Dari hasil uraian diatas, secara keseluruhan materi yang disajikan dalam buku bahasa Arab kurikulum 2013 Madrasah Aliyah Kelas X ini sudah memenuhi standar yang terdapat dalam kompetensi inti (KI) berdasarkan kurikulum 2013.52

b. Kompetensi Dasar (KD)

\section{Bab 1 : Bيانات الشخصية}

1.1 Mensyukuri kesempatan dapat mempelajari bahasa Arab sebagai bahasa pengantar komunikasi internasional yang diwujudkan dalam semangat belajar.

2.1 Menunjukkan perilaku santun dan peduli dalam melaksanakan komunikasi antara pribadi dengan guru dan teman.

3.1 Memahami cara penyampaian serta cara merespon, mengidentifikasi, dan cara memberitahu dan menanyakan tentang fakta, perasaan, dan sikap terkait

\footnotetext{
52 Hasil Dokumentasi Buku Ajar...., hlm 1.
} 
Alam Budi Kusuma, Nunung Sair : Analisis Buku Ajar Bahasa Arab Kurikulum 2013 Madrasah Aliyah Kelas X

topik البيانات الشخصية, mendeskripsikan secara sederhana unsur kebahasaan, struktur teks النكرة و المعرفة والضمائر والإضافة بعنى اللام.

4.1 Mensimulasikan dialog sederhana tentang cara merespon ungkapan sederhana tentang cara memberitahu dan menanyakan fakta, perasaan dan sikap, menyusun teks lisan dan tulis sederhana mengenai topik البيانات الشخصية dengan meperhatikan unsur kebahasaan, struktur teks dan budaya secara benar dan sesuai dengan النكرة و المعرفة و الضمائر والإضافة بمنى اللام.

Pada materi dalam subbab qira'ah yang bertema tentang identitas pribadi, sebagai salah satu ajaran dalam islam yaitu tentang ta'aruf, hal ini berkaitan dengan sikap spiritual (KD 1.1) dan sikap sosial (KD 3.1) yaitu siswa diajarkan untuk saling mengenal antara satu dengan yang lain. Sedang dalam subbab tarkib menyentuh ranah pengetahuan (KD 3.1) karena siswa mengetahui dan memahami kaidah yang digunakan dalam bahasa Arab dan النكرة و المعرفة والضمائر menerapkannya dalah hal ini sesuai dengan yang telah dijelaskan guru secara tepat dan benar. Pada bagian subbab kitabah menyangkut ranah kemampuan dan keterampilan siswa (KD 4.1) siswa mampu mengerjakan latihan-latihan berupa kata atau kalimat 
النكرة و المعرفة والضمائر sederhana secara lisan atau tulisan sesuai yang telah dipelajari. ${ }^{53}$

\section{Bab 2 : المرافق العامة في المدرسة}

1.1 Mensyukuri kesempatan dapat mempelajari bahasa Arab sebagai bahasa pengantar komunikasi internasional yang diwujudkan dalam semangat belajar.

2.1 Menunjukkan perilaku santun dan peduli dalam melaksanakan komunikasi antara pribadi dengan guru dan teman.

3.1 Memahami cara penyampaian serta cara merespon, mengidentifikasi, dan cara memberitahu dan menanyakan tentang fakta, perasaan, dan sikap terkait topik المرافق العامة في المدرسة, mendeskripsikan secara sederhana unsur kebahasaan, struktur teks المبتدأ و الخبر (صفة).

4.1 Mensimulasikan dialog sederhana tentang cara merespon ungkapan sederhana tentang cara memberitahu dan menanyakan fakta, perasaan dan sikap, menyusun teks المرافق العامة في المدرسة lisan dan tulis sederhana mengenai topik dengan meperhatikan unsur kebahasaan, struktur teks المبتدأ و الخبر dan budaya secsara benar dan sesuai dengan (صف)

${ }^{53}$ Hasil Dokumentasi Buku Ajar.... , hlm 1-2. 
Alam Budi Kusuma, Nunung Sair : Analisis Buku Ajar Bahasa Arab Kurikulum 2013 Madrasah Aliyah Kelas X

Dalam bab ini, kompetensi yang harus dibentuk pada diri siswa dengan meyakini bahwa mesnsyukuri kesempatan dalam mempelajari bahasa Arab adalah anugerah yang diberikan oleh Allah SWT dengan wujud bersemangat dalam mempelajari bahasa Arab (KD 1.1). Materi subbab hiwar jika ditelaah secara mendalam menyentuh ranah sikap sosial (KD 2.1) siswa melakukan interaksi dengan guru maupun siswa.

Sedangkan dalam subbab tarkib dan qira'ah dengan tema tentang fasilitas umum di sekolah yang menyentuh ranah pengetahuan siswa (KD 3.2) yaitu siswa mampu mengetahui, memahami dan mengidentifikasi tentang kaidah-kaidah sesuai المبتدأ و الخبر (صفة). Dan materi dalam subbab kitabah, disajikan pertanyaan berupa teks sederhana yang kerajakan oleh siswa secara mandiri, secara lisan maupun tulisan dengan tepat dan benar sesuai dengan kaidah المبتدأ و الحبر (صفة). Materi ini menyangkut ranah kemampuan dan keterampilan (KD-4.1). ${ }^{54}$

\section{Bab 3 : الحياة في الأسرة و في السكن}

1.1 Mensyukuri kesempatan dapat mempelajari bahasa Arab sebagai bahasa pengantar komunikasi internasional yang diwujudkan dalam semangat belajar.

${ }^{54}$ Hasil Dokumentasi Buku Ajar.... , hlm 16-17. 
2.1 Menunjukkan perilaku santun dan peduli dalam melaksanakan komunikasi anara pribadi dengan guru dan teman.

3.1 Memahami cara penyampaian serta cara merespon, mengidentifikasi, dan cara memberitahu dan menanyakan tentang fakta, perasaan, dan sikap terkait topik الحياة في الأسرة و في السكن, mendeskripsikan secara النكرة و المعرفة (بأل sederhana unsur kebahasaan, struktur teks

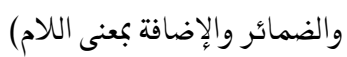

4.1 Mensimulasikan dialog sederhana tentang cara merespon ungkapan sederhana tentang cara memberitahu dan menanyakan fakta, perasaan dan sikap, menyusun teks الحياة في الأسرة و في dengan meperhatikan unsur kebahasaan, struktur teks dan budaya secsara benar dan sesuai dengan النكرة و . المعرفة (بأل و الضمائر بعنى اللام)

Materi hiwar yang bertema kehidupan dalam keluarga, menyentuh pada ranah sikap sosial (KD 2.1), karena terdapat interaksi antara siswa dalam melakukan komunikasi. Sedangkan dalam subbab tarkib materi tentang "jumlah ismiyyah" menyentuh ranah pengetahuan (KD 3.1), siswa mempelajari cara menyusun kalimat dalam bahasa Arab sesuai dengan (بأل والضمائر بعنى اللام). Dan materi dalam 
Alam Budi Kusuma, Nunung Sair : Analisis Buku Ajar Bahasa Arab Kurikulum 2013 Madrasah Aliyah Kelas X

subbab kitabah berkaitan dengan ranah kemampuan dan keterampilan (KD 4.1), untuk mengetahui sejauh mana kemampuan siswa dalam mensimulasikam dialog sederhana berupa teks tertulis maupun lisan, dan merangkai kata atau kalimat dengan benar sesuai dengan النكرة و المعرفة (بأل و الضمائر بعنى

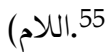

\section{Bab 4 : هواية الطلاب و المعرض}

1.1 Mensyukuri kesempatan dapat mempelajari bahasa Arab sebagai bahasa pengantar komunikasi internasional yang diwujudkan dalam semangat belajar.

2.1 Menunjukkan perilaku santun dan peduli dalam melaksanakan komunikasi antara pribadi dengan guru dan teman.

3.1 Memahami cara penyampaian serta cara merespon, mengidentifikasi, dan cara memberitahu dan menanyakan tentang fakta, perasaan, dan sikap terkait topik هواية الطلاب و المعرض mendeskripsikan secara sederhana unsur kebahasaan, struktur teks المصدر ؟معاني حروف الجر

4.1 Mensimulasikan dialog sederhana tentang cara merespon ungkapan sederhana tentang cara memberitahu dan menanyakan fakta, perasaan dan sikap, menyusun teks

${ }^{55}$ Hasil Dokumentasi Buku Ajar.... , hlm 30-31. 
هواية الطلاب والمعرض lisan dan tulis sederhana mengenai topik dengan meperhatikan unsur kebahasaan, struktur teks المصدر ؟معاني dan budaya secara benar dan sesuai dengan

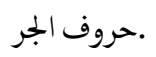

Untuk membentuk kompetensi dalam diri siswa, hal yang harus dilakukan guru terlebih dahulu adalah memotivasi dan membiasakan siswa agar menyadari bahwa mempelajari bahasa Arab adalah satu satu anugerah yang diberikan oleh Allah KD 1.1 (sikap spiritual). Subbab hiwar yang bertema "hobi dan dan keahlian siswa" berkaitan dengan KD 2.1, yaitu menunjukkan perilaku santun dan peduli dalam melaksanakan komunikasi antara pribadi dengan guru dan teman.

Kemudian materi yang disajikan dalam dalam tema terdapat dalam subbab qira'ah yang berkaitan dengan KD 3.1, siswa memahami cara penyampaian dan merespon terkait tema berdasarkan unsur kebahasaan dan struktur teks sesuai المصدر ؟ معاني حروف الجر secara tepat. Dan KD 4.1 (kemapuan dan keterampilan) dalam subbab kitabah dengan siswa mampu menyusun teks sederhana lisan maupun tulisan berdasarkan unsur 5ebahasaan sesuai المصدر ؟معاني حروف الجر

${ }^{56}$ Hasil Dokumentasi Buku Ajar.... , hlm 50-51. 
Alam Budi Kusuma, Nunung Sair : Analisis Buku Ajar Bahasa Arab Kurikulum 2013 Madrasah Aliyah Kelas X

\section{Bab 5 : المهنة و الحياة}

1.1 Mensyukuri kesempatan dapat mempelajari bahasa Arab sebagai bahasa pengantar komunikasi internasional yang diwujudkan dalam semangat belajar.

2.1 Menunjukkan perilaku santun dan peduli dalam melaksanakan komunikasi antara pribadi dengan guru dan teman.

3.1 Memahami cara penyampaian serta cara merespon, mengidentifikasi, dan cara memberitahu dan menanyakan tentang fakta, perasaan, dan sikap terkait topik المهنة و الحياة, mendeskripsikan secara sederhana unsur ليس عندي/معي و العطف kebahasaan, struktur teks

4.1 Mensimulasikan dialog sederhana tentang cara merespon ungkapan sederhana tentang cara memberitahu dan menanyakan fakta, perasaan dan sikap, menyusun teks lisan dan tulis sederhana mengenai topik المهنة و الحياة dengan memperhatikan unsur kebahasaan, struktur teks ليس عندي/معي و dan budaya secara benar dan sesuai dengan العطف - م العف

Dalam membentuk kompetensi siswa, guru membiasakan siswa untuk mensyukuri kesempatan dalam belajar bahasa Arab adalah salah satu anugerah yang diberikan oleh Allah (KD 1.1). Materi yaitu terdapat dalam 
subbab hiwar terkait tema المهنة و الحياة yaitu siswa melakukan percakapan dengan temannya, hal tersebut sesuai dengan menunjukkan sikap santun dalam melakukan komunikasi (KD 2.1). Terkait KD-3.1 (aspek pengetahuan) terdapat pada materi subbab qira'ah memahami teks sederhana terkait tema kemudian disesuaikan dengan ليس عندي/معي و العطف dengan tepat dan benar. Dan terkait KD-4.1(aspek kemampuan dan keterampilan) terdapat dalam dialog tentang المهنة siswa mensimulasikan latihan sederhana dengan memperhatikan unsur kebahasaan dan struktur teks sesuai .5ندي/معي و العطف ليس

\section{Bab 6 : Bهنة والنظام}

1.1 Mensyukuri kesempatan dapat mempelajari bahasa Arab sebagai bahasa pengantar komunikasi internasional yang diwujudkan dalam semangat belajar.

2.1 Menunjukkan perilaku santun dan peduli dalam melaksanakan komunikasi antara pribadi dengan guru dan teman.

3.1 Memahami cara penyampaian serta cara merespon, mengidentifikasi, dan cara memberitahu dan menanyakan tentang fakta, perasaan, dan sikap terkait

${ }^{57}$ Hasil Dokumentasi Buku Ajar.... , hlm 74-75. 
Alam Budi Kusuma, Nunung Sair : Analisis Buku Ajar Bahasa Arab Kurikulum 2013 Madrasah Aliyah Kelas X

topik المهنة والنظام, mendeskripsikan secara sederhana unsur kebahasaan, struktur teks (مبتداً (ضمائر الجمع) + خبر(المضارع).

4.1 Mensimulasikan dialog sederhana tentang cara merespon ungkapan sederhana tentang cara memberitahu dan menanyakan fakta, perasaan dan sikap, menyusun teks lisan dan tulis sederhana mengenai topik المهنة وانظام dengan meperhatikan unsur kebahasaan, struktur teks dan budaya secsara benar dan sesuai dengan + (ضمبأر الجمع) (ضمأ) خبر(المضارع).

Bab terakhir ini tidak disajikan subbab hiwar seperti dalam lima bab sebelumnya, namun langsung pada materi dalam subbab qira'ah dengan judul المهنة yang terkait dengan KD 3.1, siswa mampu memahami dan mengidentifikasi dan menanyakan unsur kebahasaan dan struktur teks sesuai مبتدأ) secara tepat. Dalam subbab al-kitabah, memuat teks sederhana berupa pertanyaan yang dikerjakan oleh siswa secara mandiri dari kata atau kalimat sesuai dengan kaidah yang dipelajari dalam bab ini. Hal ini terkait dengan aspek kemampuan dan keterampilan siswa (KD 4.1). ${ }^{58}$

Semua aspek dalam kompetensi dasar (KD) adalah bagian dari kompetensi inti (KI), agar tercapainya aspek KI

${ }^{58}$ Hasil Dokumentasi Buku Ajar.... , hlm 95-96. 
maka dirincilah dalam KD dengan tema-tema yang sudah disesuaikan dengan masing-masing kompetensi.

c. Kesesuaian antara buku guru dan buku siswa

Tabel 4 : Kesuaian Antara Buku Guru Dengan Buku Siswa

\begin{tabular}{|c|c|c|}
\hline Bab & Buku guru & Buku siswa \\
\hline الباب ألاؤل & البيانات الشخصية & البيانات الشخصية \\
\hline الباب الثاني & المرافق العامة في المدرسة & المرافق العامة في المدرسة \\
\hline الباب الثالث & الحياة في الآسرة و في السكن & الحياة في الآسرة و في \\
\hline الباب الرابع & هواية الطلاب و المعرض & هواية الطلاب و المعرض \\
\hline الباب الخامس & المهنة و الحياة & المهنة و الحياة \\
\hline الباب السادس & المهنة و النظام & المهنة و النظام \\
\hline
\end{tabular}

Hasil pembahasan mengenai gambaran umum buku ajar bahasa Arab kurikulum 2013 Madrasah Aliyah Kelas X, sudah menunjukkan kesesuaian antara buku ajar guru dengan buku pegangan siswa yang digunakan dalam proses belajar mengajar di jenjang Madrasah Aliyah Kelas X dan sederajat.

\section{Analisis buku ajar bahasa Arab kurikulum 2013 Madrasah Aliyah Kelas X}

Seperti yang telah dipaparkan dalam landasan teori, ada beberapa hal yang perlu diperhatikan dalam menyusun buku ajar 
Alam Budi Kusuma, Nunung Sair : Analisis Buku Ajar Bahasa Arab Kurikulum 2013 Madrasah Aliyah Kelas X

bahasa Arab menurut teori-teori Abdul Hamid sebagai berikut :

1. Isi buku

Buku ajar bahasa Arab sudah memuat kompetensi inti, kompetensi dasar, indikator, tujuan pembelajaran, dan halaman instrumen penilaian halaman 1-107. Buku ajar ini terdiri dari enam bab pembahasan disajikan dalam 2 semester. Dalam setiap babnya terdiri atas lima subbab yaitu, mufradat, istima', hiwar, tarkib, qira'ah, dan kitabah berdasarkan kurikulum 2013 yang terdiri dari empat kompetensi inti, dimana KI-1 menyentuh ranah sikap keagamaan, KI-2 berkaitan dengan sikap sosial, KI-3 berkaitan dengan aspek pengetahuan, dan KI-4 berkaitan dengan kemampuan dan keterampilan siswa.

Berdasarkan data tersebut dalam buku ajar bahasa Arab kurikulum 2013, hal-hal yang telah disebutkan sebelumnya saling berkaitan antara tema-tema yang disajikan buku tersebut.

a. Mufradat yaitu daftar kosa kata yang disajikan sudah disesuaikan dengan tema.

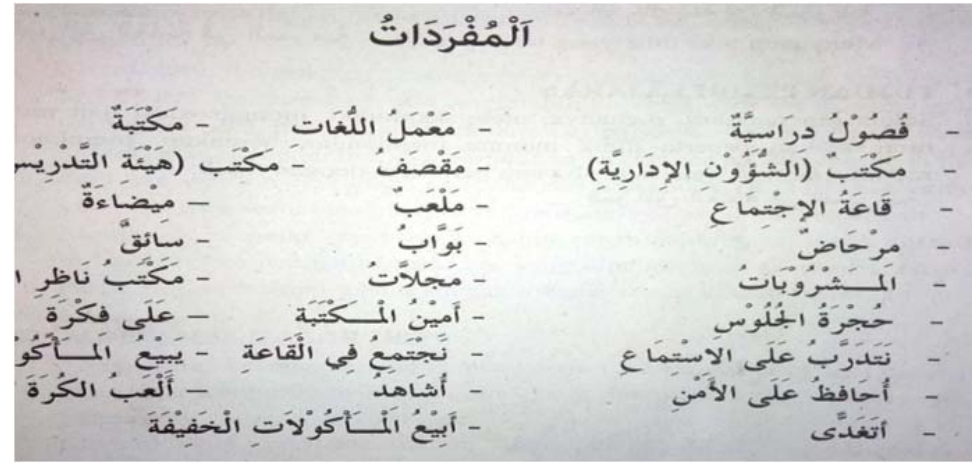

Gambar 4 : Contoh Materi Mufradat 
b. Istima' yaitu mendengar/menyimak bacaan yang dibacakan langsung oleh guru atau melalui audio.

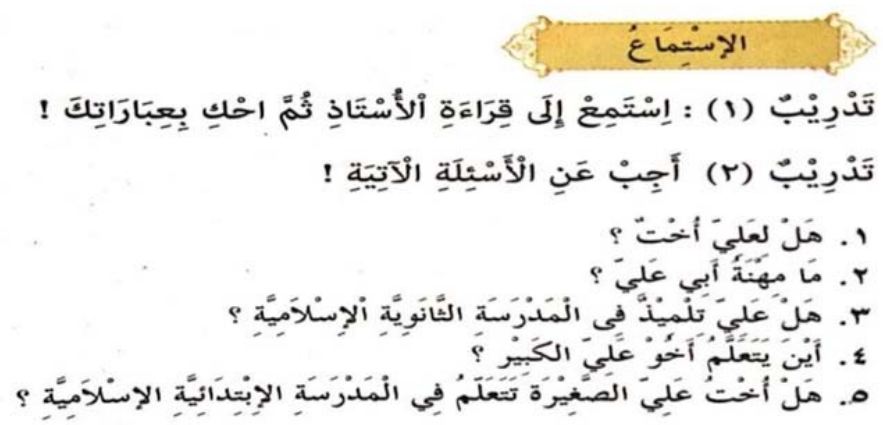

Gambar 5 : contoh subbab Istima'

Siswa mendengarkan terlebih dahulu apa yang akan dibacakan oleh guru, kemudian menjawab soal-soal yang disajikan dalam lembar istima' dalam buku ajar tersebut.

c. Hiwar yaitu teks percakapan yang di praktikkan langsung oleh siswa secara berpasangan.

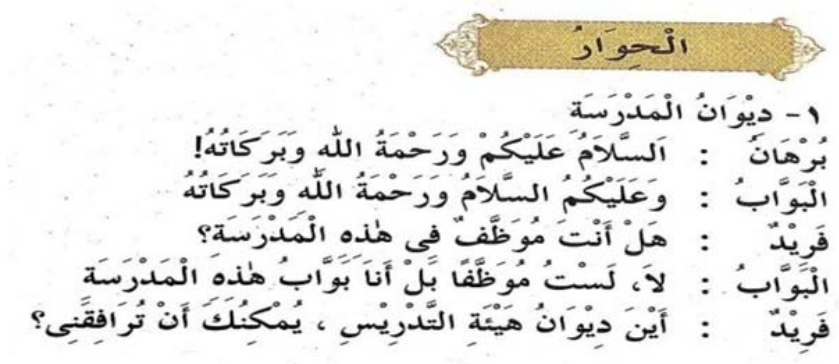

Gambar 6 : Contoh Subbab Hiwar

d. Tarkib yaitu siswa diajarkan mengenai kaidah-kaidah bahasa Arab disetiap tema pembahasan. 
Alam Budi Kusuma, Nunung Sair : Analisis Buku Ajar Bahasa Arab Kurikulum 2013 Madrasah Aliyah Kelas X

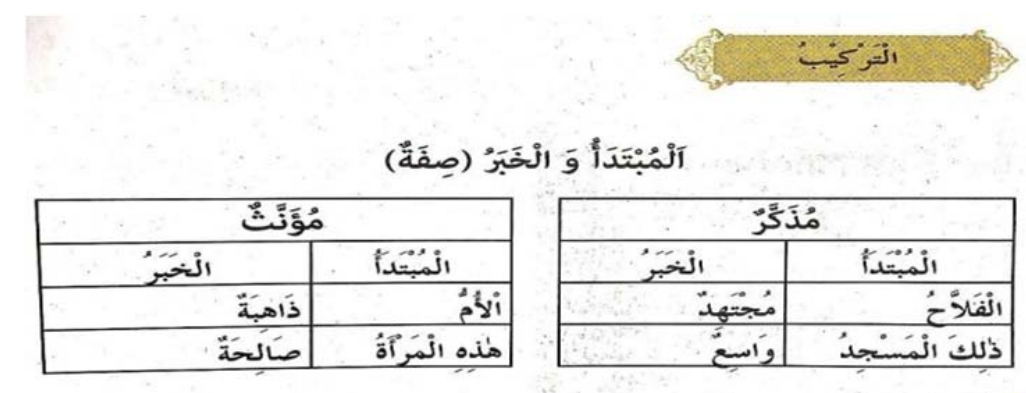

Gambar 7 : Contoh Subbab Tarkib

e. Qira'ah yaitu kegiatan membaca yang dilakukan oleh siswa dengan arahan guru.

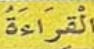

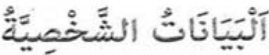

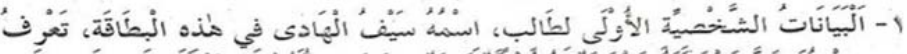

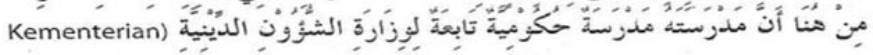

(Agama

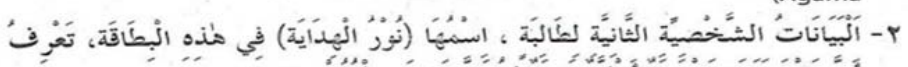

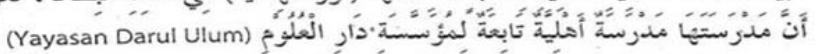

\section{Gambar 8 : Contoh subbab Qira'ah}

f. Kitabah yaitu siswa dilatih untuk menulis bahasa Arab sesuai dengan kaidah yang benar.

\section{الكِكتابَة}

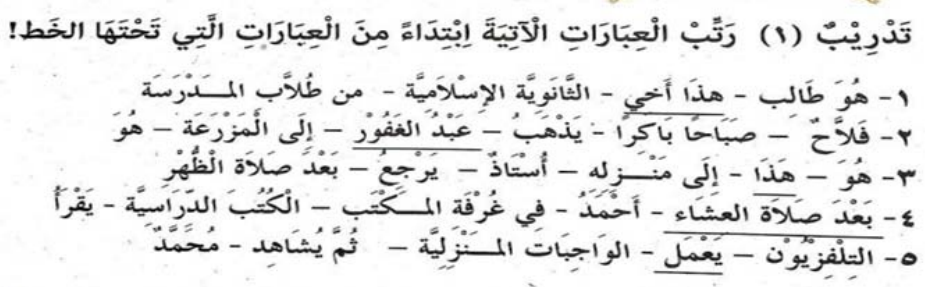

Gambar 9 : Contoh subbab Kitabah 
2. Ketepatan cakupan

Ketepatan cakupan terlihat dari penyusunan materi yang sudah memperlihatkan KI dan KD yang sudah ditetapkan. materi yang dijabarkan dalam buku ajar Bahasa Arab kurikulum 2013 Madrasah Aliyah Kelas X pada semester gasal berupa :

a. البيانات الشخصية yaitu membahas tentang identitas pribadi siswa menggunakan bahasa Arab.

b. المرافق العامة في المدرسة yaitu pembahasan mengenai fasilitas-fasilitas umum disekolah.

c. الحياة في الأسرة وفي السكن membahas tentang kehidupan di keluarga dan asrama siswa.

Sedangkan tema-tema dalam buku ajar bahasa Arab Kurikulum 2013 Madrasah Aliyah Kelas X pada semester genap berupa :

a. حواية الطلاب والمعرض membahas mengenai hobi dan keahlian siswa.

b. المهنة و الحياة membahas mengenai profesi dan kehidupan.

c. المهنة النظام membahas menegnai profesi dan aturan.

Berdasarkan cakupan materi yang telah dipaparkan diatas, terlihat bahwa tema-tema yang disajikan dalam buku ajar bahasa Arab ini sudah sesuai dengan kurikulum 2013.

3. Ketercernaan materi

Ketercernaan materi artinya materi yang disajikan dalam buku ajar dengan tujuan buku tersebut mampu memberikan 
Alam Budi Kusuma, Nunung Sair : Analisis Buku Ajar Bahasa Arab Kurikulum 2013 Madrasah Aliyah Kelas X

kemudahan untuk dicerna dan difahami oleh sasaran pengguna buku ajar atau siswa. Seperti yang telah disebutkan sebelumnya bahwa terdapat enam hal yang mendukung tujuan tersebut, yaitu :

a. Pemaparan yang logis

Dalam penyusunan buku ajar bahasa Arab ini, terdapat enam bagian yang digunakan sebagai langkahlangka untuk menyusun pembelajaran yang disesuaikan dengan kurikulum 2013 dengan pendekatan ilmiah (scientific approach) sebagai berikut :

1) Mufradat memuat gambar dan susunan kosa kata yang berbeda dengan jumlah antara 10-20 kosa kata dalam setiap bab yang berkaitan erat dengan tema yang akan dipelajari.

2) Istima' memuat percakapan yang akan dibacakan oleh guru menggunakan buku pegangan guru dan disimak dengan baik oleh siswa kemudian siswa diberikan soal untuk menjawab pertanyaan yang ada dalam buku pegangan siswa.

3) Hiwar yang disajikan sudsh berkaitan dengan tema yang dibahas dalam setiap bab dalam buku bahasa Arab ini. Percakapan akan dilakukan siswa bersama dengan teman, bertujuan untuk melatih siswa berbicara dengan menggunakan bahasa Arab. 
4) Tarkib memuat kaidah-kaidah berkaitan dengan tata bahasa Arab yang akan dipelajari secara urut, mulai dari bab pertama memuat yaitu tentang isim nakirah, contohnya , dan isim ma'rifah, contohnya : مدرسة ,طالب ,مسجد ,كتاب : . Bab 2 tentang mubatada dan khabar (sifat), contohnya : مجتهد الفلاح, الأم ذاهبة Bab 3 tentang jumlah ismiyyah, contohya : هو يذهب الى المدرسة. Bab 4 tentang mashdar,

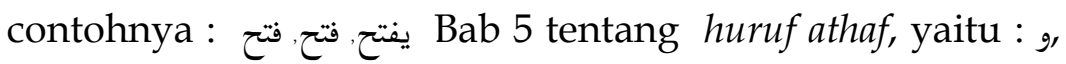
حتى رثم ,أو ,لكن ,نل ,لا ,ف Dan bab 6 memuat kaidah jumlah ismiyyah (jamak), contohnya : هن يذهبن إلى المدرسة.

Penyajian materi dalam subbab tarkib tersebut membahas tentang kaidah-kaidah yang terdapat dalam bahasa Arab. Dimulai dari kaidah dasar sampai dengan cara menyusun kalimat menggunakan bahasa Arab.

a) Qira'ah memuat bacaan yang berkaitan dengan tema dan sudah disesuaikan dengan tarkib yang disajikan dalam setiap bab pada buku ajar bahasa Arab ini.

b) Kitabah, subbab ini memuat latihan-latihan yang berkaitan dengan tema yang telah dipelajari, karena dapat membantu siswa untuk mengingat dan mengulang kembali materi tersebut.

Materi yang disajikan dalam buku ajar bahasa Arab ini sudah disusun secara logis. Sehingga mampu melatih 
Alam Budi Kusuma, Nunung Sair : Analisis Buku Ajar Bahasa Arab Kurikulum 2013 Madrasah Aliyah Kelas X

dan membiasakan siswa dalam berpikir dan mempelajari materi secara berurutan dan tidak loncat-loncat.

b. Penyajian materi yang berurutan

Penyajian materi dalam buku ajar bahasa Arab seperti yang telah dipaparkan sebelumnya, sudah disusun secara sistematis sesuai dengan konsep K-13 dengan pendekatan saintifik yaitu : mengamati, menanya, mengasosiasi, mengeksplorasi, dan mengkomunikasikan. Materi disusun secara berurutan dimulai dari tahap pengenalan dalam bab 1 sampai dengan bab 6. Tujuannya untuk melatih siswa dalam berpikir secara runtun, khususnya urutan dalam mempelajari dan memahami materi yang terdapat pada subbab tarkib dalam setiap tema.

c. Terdapat contoh

Penyajian contoh dalam buku ajar bahasa Arab kurikulum 2013 Madrasah Aliyah Kelas X sudah sesuai dengan substansi materi dan mampu memberikan pemahaman kepada siswa dam memudahkan siswa dalam memahami materi yang disajikan dalam buku ajar.

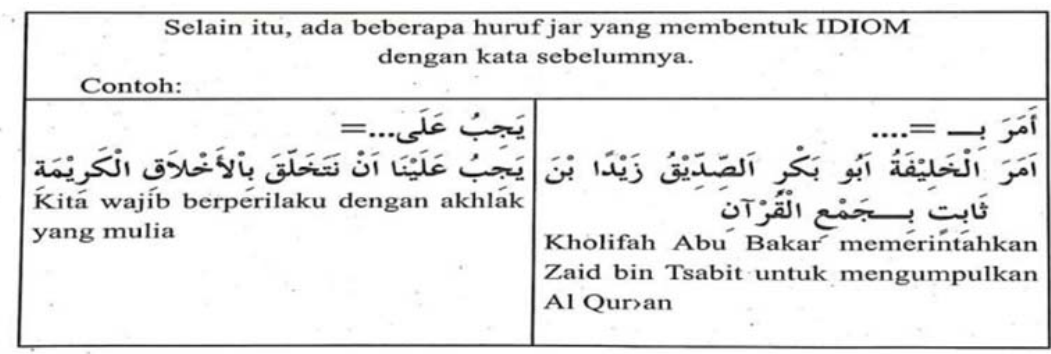

Gambar 10 : Penyajian Contoh

\section{IHTIMAM}


Data tersebut menunjukan bahwa pemberian contoh dalam buku ajar bahasa Arab ini sudah sesuai dengan psikologi media pembelajaran. Namun, tidak terlalu banyak contoh yang disajikan, karena buku tersebut lebih menekan pada kedalaman materi. ${ }^{59}$

d. Alat bantu

Alat bantu biasa disajikan dalam buku bahasa Arab ini sudah bersifat intruktif sesuai dengan kata-kata dan langkahlangkah yang disajikan dalam setiap pembahasannya. Terlebih buku ini sudah memiliki alat bantu yang baik, khususnya dilengkapi dengan buku pegangan untuk guru, sehingga menjandi alat bantu untuk membimbing siswa dalam proses pembelajaran bahasa Arab dengan mudah dan terarah.

e. Format yang tertib

Berdasarkan data dalam buku ajar bahasa Arab MA ini, format dan sistemaatika sudah disajikan secara konsisten dalam setiap babnya. Diawali dengan penyajian gambar yang sesuai dengan tema, kemudian disusul dengan mufradat yang relevan dan mudah bagi siswa. Ilustrasi gambar yang sesuai dengan bahasan yang disajikan. Dengan demikian, format yang disajikan dalam buku ajar bahasa Arab kurikulum 2013 Madrasah Aliyah Kelas X ini sudah disajikan

${ }^{59}$ Hasil Dokumentasi Buku Ajar.... , hlm 62. 
Alam Budi Kusuma, Nunung Sair : Analisis Buku Ajar Bahasa Arab Kurikulum 2013 Madrasah Aliyah Kelas X

dengan baik, tertib dan konsisten mulai dari halaman 1 sampai halaman 107.

f. Penjelasan tentang relevansi dan manfaat buku ajar

Di poin ini peneliti tidak menemukan adanya penjelasan mengenai relevansi dan manfaat buku ajar, atau telah disatukan dalam kata pengantar. Namun demikian, buku ajar yang baik hendaknya mencantumkan tujuan dan target yang ingin dicapai dalam proses pembelajaran bahasa Arab. Sehingga dapat diukur dengan jelas tujuan tersebut.

4. Aspek bahasa

Bahasa pengantar dalam buku ajar ini lebih banyak menggunakan bahasa Arab. Sementara penggunaan bahasa indonesia hanya pada pembahasan tarkib pada setiap tema pembahasan. Namun demikian, penggunaan bahasa Arab sepenuhnya masih menyulitkan siswa disekolah tersebut, mengingat mayoritas siswa berasal dari lulusan SMP yang notabene belum mengetahui sama sekali perihal bahasa Arab. Sehingga dalam menyampaikan materi guru perlu menyesuaikan dengan pengetahuan dan kemampuan siswa.

Buku ajar bahasa Arab Madrasah Aliyah Kelas X ini menggunakan bahasa Arab fushah yang disesuaikan dengan teori dari Dr, Nashir dan Dr. Abdul Hamid dalam penyusunan buku pembelajaran bahasa Arab. Jika melihat pada ketepatan penggunaan kaidah bahasa, kata, dan kalimat sebagian besar sudah sesuai dengan kaidah bahasa Arab (nahwu-shorof). Namun

\section{IHTIMAM}


dalam kekeliruan dalam penulisan harakat seperti dalam tabel berikut.

Tabel 5 : Kekeliruan Dalam Penulisan Harakat

\begin{tabular}{|c|c|}
\hline $\begin{array}{l}\text { Tidak terdapat harakat } \\
\text { akhir }\end{array}$ & $\begin{array}{c}\text { Kesalahan penulisan } \\
\text { harakat akhir }\end{array}$ \\
\hline يَزْرَعَا ن & وهذا رسمُ المَلْعَبُ \\
\hline المَجََّاَات & فِي الأُسرةٌ \\
\hline اََفْرًَا نَافِعِين & في المَدْرَسَسة \\
\hline
\end{tabular}

Kekeliruan yang terdapat dalam buku ajar bahasa Arab ini hanya dalam penulisan harakatnya, yaitu pada penulisan harakat akhir yang tidak sesuai dengan kaidah bahasa Arab. Namun, hal ini tidak terlalu mempengarui dalam proses belaja siswa, jika guru memberikan penjelasan yang baik dan tepat.

5. Pengemasan atau perwajahan

Isi buku telah mencerminkan isi materi buku ajar bahasa Arab kurikulum 2013 Madrasah Aliyah Kelas X. Penempatan unsur tata letak pada setiap bab seperti judul, sub judul, kata pengantar, dan ilustrasi sudah konsisten serta teks pada akhir paragraf sudah terpisah dengan jelas.

Tata letak pada bidang margin sudah proporsional dan sama antara dua halaman yang berdampingan. Halaman cetak berjumlah genap, yaitu 112 halaman. Ukuran huruf pada setiap judul bab lebih besar dari huruf subbab, sehingga 
Alam Budi Kusuma, Nunung Sair : Analisis Buku Ajar Bahasa Arab Kurikulum 2013 Madrasah Aliyah Kelas X

menginformasikan mengenai apa yang akan dibahas dalam bab tersebut.

Penempatan gambar hiasan yang terdapat dalam setiap bab disesuaikan dengan tata letak sehingga tidak mengganggu judul, teks, dan angka pada halaman. Buku ajar bahasa Arab ini juga tidak banyak menggunakan kombinasi jenis huruf, hanya mengunakan huruf Times New Roman, 12pt A_Nefel_Adeti_Qelew 18p, dan Adobe Arabic 24. Buku ini juga tidak menggunakan huruf hiasan dekoratif, penggunaan variasi huruf seperti bold, italic yang tidak berlebihan dan digunakan untuk menekan pada materi yang dianggap penting. ${ }^{60}$

6. Ilustrasi

Penyajian ilustrasi dalam buku ajar bahasa Arab ini bertujuan untuk membuat materi yang disajikan terlihat lebih menarik, dapat membantu dan memudahkan siswa dalam memahami materi yang dipelajarinya. Ilustrasi sendiri bisa berupa gambar, tabel, grafik,foto, sketsa, dan simbol. Contoh penggunaan ilustrasi gambar dalam buku ajar bahasa Arab Kurikulum 2013 Madrasah Aliyah Kelas X dibawah ini :

${ }^{60}$ Hasil Dokumentasi Buku Ajar.... , hlm i-112. 


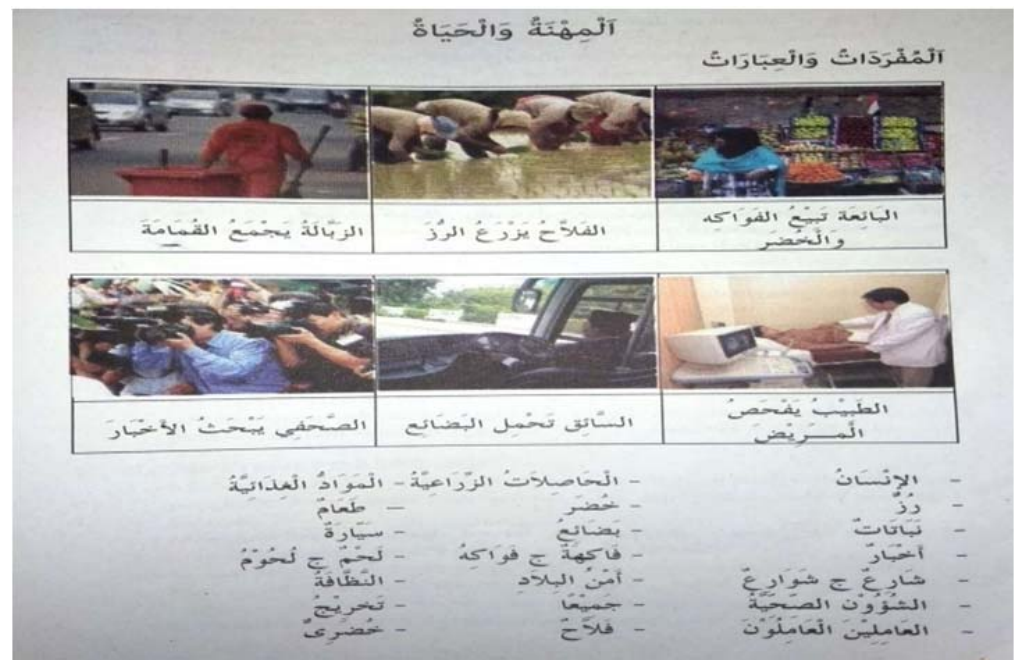

Gambar 11 : Penyajian Ilustrasi

Berdasarkan data tersebut dapat disimpulkan bahwa penyajian ilustrasi dalam buku ajar bahasa Arab ini sudah sesuai dengan tema dan layak untuk digunakan dalam proses pembelajaran bahasa Arab di sekolah. ${ }^{61}$

7. Kelengkapan komponen

Kelengkapan komponen terdiri dari komponen utama yang berisi tentang topik utama yang akan disampaikan kepada siswa dan harus dikuasai oleh siswa. Seperti yang terdapat dalam tujuan yaitu, siswa mampu mendengar, bercakap, membaca, dan menulis dengan menggunakan bahasa Arab sesuai dengan tema dalam setiap babnya.

Komponen pelengkap adalah komponen lain sebagai pendukung media cetak berupa gambar-gambar, VCD, DVD,

${ }^{61}$ Hasil Dokumentasi Buku Ajar...., hlm 76. 
Alam Budi Kusuma, Nunung Sair : Analisis Buku Ajar Bahasa Arab Kurikulum 2013 Madrasah Aliyah Kelas X

kaset, dan lain sebagainya yang dapat menunjang pemahaman siswa dalam memahami materi dalam buku ajar bahasa Arab. Namun, dalam buku ajar bahasa Arab kurikulum 2013 Madrasah Aliyah Kelas X belum dilengkapi dengan kaset, VCD, maupun DVD.

Komponen evaluasi dalam buku ajar bahasa Arab telah memuat soal-soal latihan baik secara individual maupun kelompok agar siswa dapat mencari informasi lebih lanjut mengenai materi-materi yang telah disampaikan oleh guru, baik dalam bentuk media visual maupun non-visual.

Berikut evaluasi yang terdapat didalam buku ajar bahasa Arab Kurikulum 2013 Madrasah Aliyah Kelas X, yaitu :
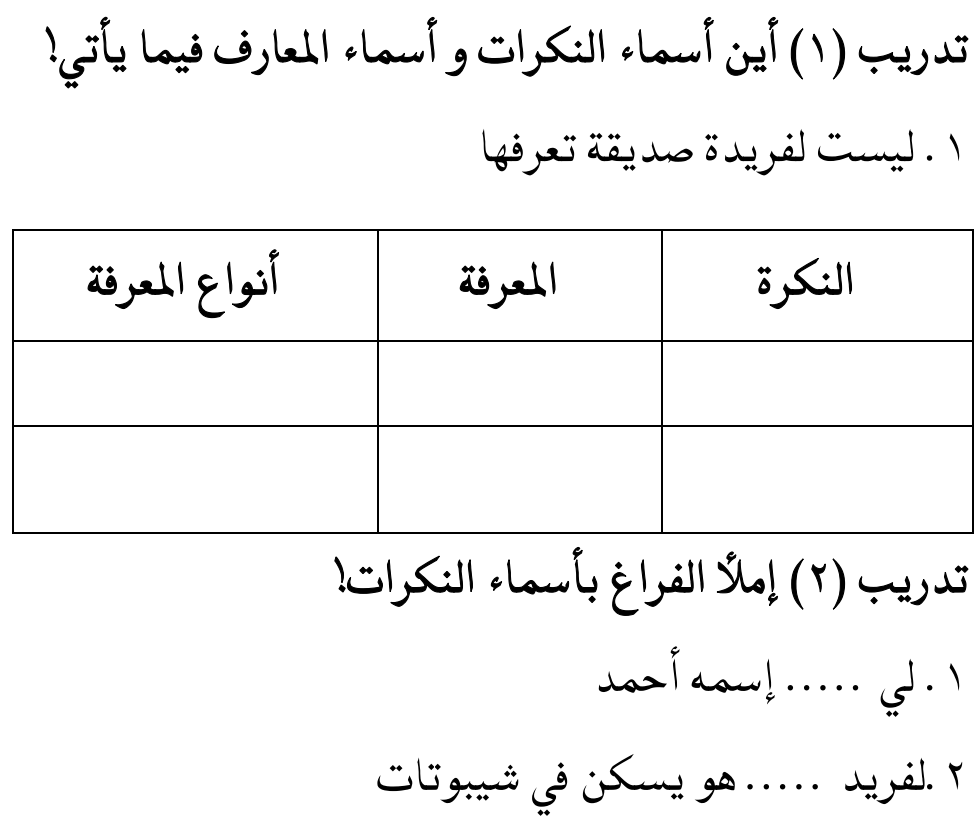


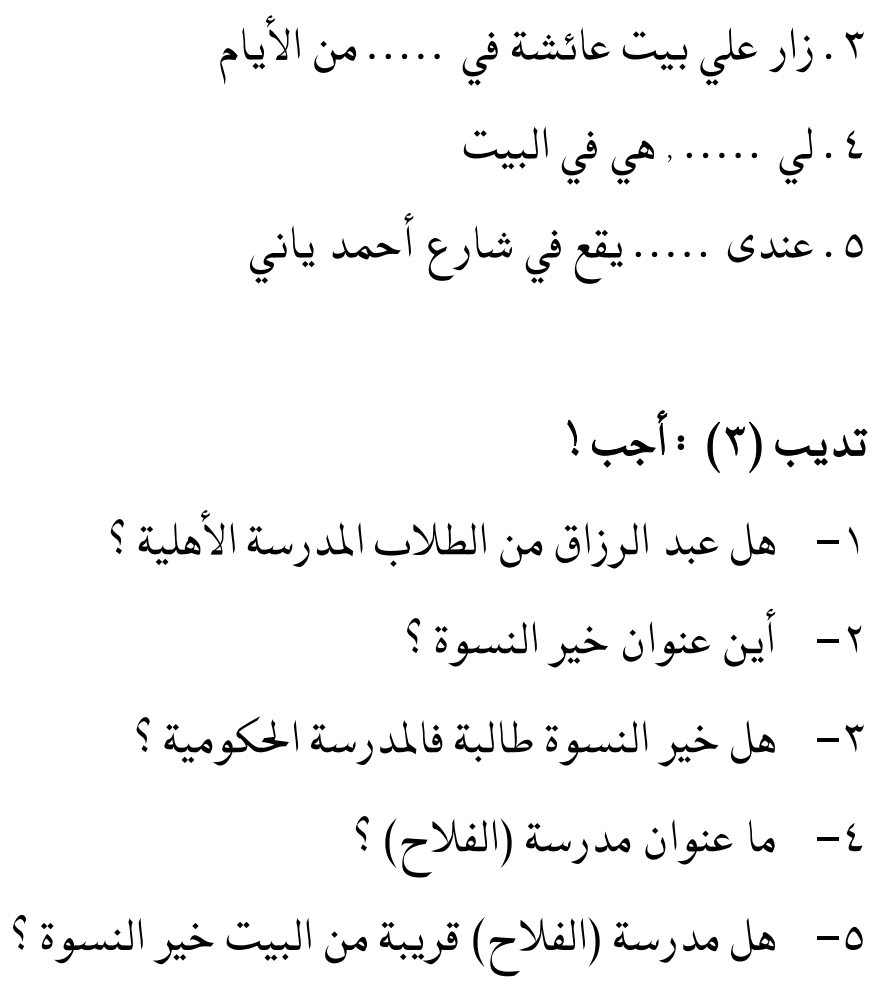

Berdasarkan data di atas, soal-soal evaluasi disajikan untuk menstimulasi siswa dalam mengingat kembali materi yang telah dipelajari sebelumnya, dan merangsang daya ingat siswa terhadap materi yang telah dipelajarinya. Soal-soal latihan tersebut bisa menjadi tolak ukur untuk melihat sejauh mana pemahaman siswa terhadap materi yang disampaikan oleh guru. Hal tersebut bisa digunakan untuk bahan evaluasi dalam proses pembelajaran yang akan datang bisa menjadi lebih baik lagi. ${ }^{62}$

${ }^{62}$ Hasil Dokumentasi Buku Ajar.... , hlm 10-11. 
Alam Budi Kusuma, Nunung Sair : Analisis Buku Ajar Bahasa Arab Kurikulum 2013 Madrasah Aliyah Kelas X

\section{Kesimpulan}

1. Kesesuaian Penyajian Buku Ajar Menurut Teori Abdul Hamid

Dari hasil analisis sumber belajar dengan objek penelitian Buku Ajar Bahasa Arab Kurikulum 2013 Madrasah Aliyah Kelas $\mathrm{X}$ yang ditinjau dari penyajian materi buku ajar, secara umum sudah memenuhi standar sesuai dengan kurikulum 2013 dan layak digunakan dalam proses pembelajaran. Penyajian materi buku ajar sudah bersifat komunikatif. Namun, dilihat dari penyajian materi menurut teori yang digunakan, masih terdapat beberapa kekurangan menurut teori Abdul Hamid, yaitu dalam aspek bahasa yang disajikan dalam buku ajar bahasa Arab ini masih belum disesuaikan dengan perkembangan dan pengetahuan bahasa Arab siswa khususnya siswa yang belum pernah atau minim pengetahuannya terhadap bahasa Arab. Kemudian terdapat beberapa kekeliruan dalam penulisan harakat. 


\section{Daftar Pustaka}

Abdul Hamid dkk. 2008. Pembelajaran Bahasa Arab Pendekatan, Metode, Strategi, materi, dan Media. Malang: UIN Malang Press.

Abdul Majid, Perencanaan Pembelajaran. 2013. Bandung: PT Remaja Rosda Karya.

Abudin Nata. 2009. Ilmu Pendidikan Islam. Jakarta: Rajawali Press.

Amin Haedari. 2014. Mamahami Kurikulum 2013 Panduan Praktis Untuk Guru Pendidikan Agama Islam dan Budi Pekerti. Yogyakarta: Sukses Offset.

Andi Prastowo. 2012. Panduan Kreatif Membuat Bahan Ajar Inovatif Menciptakan Metode Pembelajaran Yang Menarik Dan Menyenangkan. Yogyakarta: Diva Press.

B.P. Sitepu. 2012. Buku Teks Pelajaran. Bandung: PT Remaja Rosdakarya.

Daryanto. 2014. Pendekatan Pembelajaran Saintifik Kurikulum 2013. Yogyakarta: Gava Media.

E. Mulyasa. 2013. Pengembangan dan Implementasi Kurikulum 2013. Bandung: PT Remaja Rosdakarya.

Erna Widodo dan Muhtar. 2000. Konstruksi Kebenaran Penelitian Deskriptif. Yogyakarta: Evyrous.

Imas Kurniasih dan Berlin Sani. 2014. Sukses mengimplementasikan kurikulum 2013. Yogyakarta: Remaja Rosdakarya.

Kartini Kartono. 1996. Pengantar Metodologi Riset. Bandung: Bandar Maju.

Khairy Abusyairi. 2013. Pengembangan Bahan Ajar Bahasa Arab, Jurnal Dinamika Ilmu. STAIN Samarinda, Volume 13, Nomor 2. 
Alam Budi Kusuma, Nunung Sair : Analisis Buku Ajar Bahasa Arab Kurikulum 2013

Madrasah Aliyah Kelas X

Masnur Muslich. 2010. Textbook Writing: Dasar-dasar Pemahaman, Penulisan, dan Pemakaian Buku Teks. Yogyakarta: Ar Ruzz Media.

Muhtar. 2003. Desain Pembelajaran PAI. Jakarta: Misaka Galiza.

Peraturan Menteri Pendidikan Nasional Republik Indonesia Nomor 2 Tahun 2008 Pasal 1 (3) Tentang Buku Teks.

R. Ibrahim dan Nana Syaodih. 2010. Perencanaan Pembelajaran. Jakarta: Rineka Cipta.

Rusdi Pohan. 2007. Metodologi Penelitian Pendidikan. Bandung: Rijal Institute.

Sa'dun Akbar dan Hadi Sriwijaya. 2010. Pengembangan Kurikulum dan Pembelajaran: Ilmu Pengetahuan Sosial. Yogyakarta: Cipta Media.

Suharsimi Arikunto. 1998. Prosedur Penelitian (Suatu Pendekatan Praktek). Jakarta: Rineka Cipta.7777

Suharso dan Ana Retnoningsih. 2009. Kamus Besar Bahasa Indonesia, cet., ke- VIII. Semarang: Widya Karya.

S. Nasirudin. 2011. Teknologi Pendidikan. Jakarta: PT Bumi Aksara.

Stefan Stichsher, dkk. 2009. Metode Analisis Teks dan Wacana, terjemahan Gazali dkk. Yogyakarta: Pustaka Pelajar.

Syamsudin Asyrofi. 1998. Metodologi Pengajaran Bahasa Arab : Analisa Text Book Bahasa Arab. Yogyakarta: Sumbangsih.

Syamsuddin Asyrofi Dan Toni Pransiska. 2016. Penulisan Buku Teks Bahasa Arab Konsep Prinsip, Problematika, Dan Proyeksi. Yogyakarta: Ombak.

Ulin Nuha. 2016. Ragam Metodologi Dan Media Pembelajaran Bahasa Arab. Yogyakarta: Diva Press.

\section{IHTIMAM}

